\title{
Peningkatan Keprofesionalan Guru Dalam Pembelajaran Pendidikan Agama Islam di MTs Arrohmaniyah NW Senyiur
}

\author{
Ayatullah \\ STIT Palapa Nusantara \\ Email: ayatullahayeq@gmail.com
}

\begin{abstract}
Abstrak: Guru merupakan faktor terpenting dalam proses peningkatan kualitas pendidikan. Namun, guru sebagai makhluk sosial dan individual dalam kehidupannya sering mengalami hambatan dalam peningkatan kualitas tersebut. Adapun permasalahan yang timbul adalah bagaimana profesionalitas guru dalam pembelajaran Pendidikan Agama Islam, kendala yang dihadapi dalam peningkatan profesionalitas guru dalam pembelajaran Pendidikan Agama Islam, dan upaya apa saja yang dilakukan untuk meningkatkan profesionalitas guru dalam pembelajaran tersebut. Berpijak dari permasalahan tersebut, maka tujuan dari pembahasan ini adalah untuk mengetahui bagaimana peningkatan keprofesionalan guru dalam pembelajaran Pendidikan Agama Islam, Penelitian ini dilakukan di MTs Arrohmaiyah NW Senyiur Untuk mengumpulkan data digunakan beberapa metode yaitu, observasi, dokumentasi dan wawancara. Kemudian data yang telah terkumpul tersebut dianalisis dengan teknik analisis deskriptif kualitatif, yakni data yang dikumpulkan berupa kata-kata atau gambaran-gambaran dan bukan angka. Hasil penelitian ini juga diharapkan berguna bagi Kepala Sekolah dan Guru di MTs Arrohmaiyah NW Senyiur yang bersangkutan maupun peneliti sendiri. Berdasarkan hasil pembahasan dan penelitian diperoleh kesimpulan sebagai berikut, kemampuan guru dalam pembelajaran Pendidikan Agama Islam sudah cukup professional, terbukti semua guru memiliki ijazah keguruan, memiliki pengalaman mengajar lebih dari lima tahun, selalu membuat rencana pembelajaran, metode yang digunakan bervariasi, melakukan situasi interaksi yang baik dengan siswa, dan mengadakan evaluasi. Adapun yang menjadi kendala dalam peningkatan profesionalitas guru dalam pembelajaran Pendidikan Agama Islam adalah padatnya jam mengajar dan tidak adanya minat untuk melanjutkan pendidikan ke jenjang yang lebih tinggi serta kesejahteraan guru kurang memadai. Sedangkan upaya yang dilakukan dalam peningkatan profesionalitas guru dalam pembelajaran Pendidikan Agama Islam adalah guru selalu menguasai kompetensi, penyediaan sarana dan prasarana, kedisiplinan dan pengawasan, rapat dan seminar.
\end{abstract}

\section{Kata Kunci: Peningkatan, Profesi Guru, Pembelajaran Pendidikan Agama Islam}




\section{Pendahuluan}

Keberhasilan pendidikan dapat diukur dengan penguasaan siswa terhadap materi yang telah disampaikan oleh guru di dalam kelas. Namun, operasionalnya keberhasilan itu banyak pula ditentukan oleh manajemen pendidikan di samping dipengaruhi oleh beberapa faktor pendidikan yang harus ada dan juga terkait di dalamnya. Faktor tersebut adalah: (1) guru, (2) materi, dan (3) siswa.

Ketiga komponen utama dalam pengajaran tersebut saling berkaitan. Akan tetapi, faktor guru merupakan faktor paling dominan dalam kegiatan belajarmengajar. Guru sebagai perencana sekaligus sebagai pelaksana pembelajaran serta pemberi balikan untuk memotivasi siswa dalam melaksanakan tugas belajar. Hal ini menunjukkan bahwa posisi guru dalam dunia pendidikan sangat penting. Berdasarkan fungsi dan perannya yang sangat besar itu, maka idealnya seorang guru harus memiliki keprofesionalan dalam menjalankan tugasnya. Dengan memiliki keprofesionalan tersebut guru diharapkan dalam menjalankan tugasnya dapat mencapai hasil dan tujuan yang optimal sebagaimana telah tertuang dalam UU RI no.

20 Th. 2003 tentang Sistem Pendidikan Nasional pada BAB II pasal 3 yaitu:

Pendidikan nasional berfungsi mengembangkan kemampuan dan membentuk watak serta peradaban bangsa yang bermartabat dalam rangka mencerdaskan kehidupan bangsa, bertujuan untuk berkembangnya potensi peserta didik agar menjadi manusia yang beriman dan bertaqwa kepada Tuhan Yang Maha Esa, berakhlak mulia, sehat, berilmu, cakap, kreatif, mandiri, dan menjadi warga negara yang demokratis serta bertanggung jawab ${ }^{1}$.

Guru merupakan profesi, maka untuk menjadi guru harus memiliki sertifikasi dan etika profesi. Program sertifikasi dilakukan untuk meningkatkan keprofesionalan guru seperti yang telah dilakukan oleh Direktorat Pembinaan Perguruan Tinggi Agama Islam mlalui Proyek Peningkatan Mutu Pendidikan Dasar.

Sertifikasi kompetensi diberikan oleh penyelenggara pendidikan dan lembaga pelatihan kepada peserta didik dan warga masyarakat sebagai pengakuan terhadap kompetensi untuk melakukan pekerjaan yang diselenggarakan oleh satuan pendidikan yang terakreditasi oleh lembaga sertifikasi.

Guru mempunyai kewajiban untuk mengawasi dan membantu murid dalam kegiatan belajar mengajar. Sekaligus mereka dituntut agar meningkatkan dirinya menjadi guru yang profesional sehingga guru harus memiliki kompetensi dalan kegiatan belajar mengajar seperti menguasai bahan pelajaran sekolah, menguasai

${ }^{1}$ UURI, Sisdiknas, (Bandung: Citra Umbara, 2003), 7. 
Peningkatan Keprofesionalan Guru Dalam Pembelajaran Pendidikan Agama Islam di MTs

Arrohmaniyah NW Senyiur

proses belajar mengajar, menguasai penggunaan media dan sumber, dapat mengevaluasi hasil belajar siswa, dapat memotivasi siswa dalam belajar dan lain-lain.

Guru dapat dikatakan professional apabila memiliki kemampuan tinggi dan motivasi kerja tinggi. Guru yang memiliki motivasi yang rendah biasanya kurang memberikan perhatian kepada siswa, demikian pula waktu dan tenaga yang dikeluarkan untuk meningkatkan mutu pembelajaran sangat sedikit. Sebaliknya, guru yang memiliki motivasi tinggi biasanya tinggi sekali perhatiannya kepada siswa, demikian pula waktu yang disediakan untuk peningkatan mutu pendidikan sangat banyak.

Guru yang memahami kedudukan dan fungsinya sebagai pendidik yang profesional selalu berkeinginan untuk tumbuh dan berkembang sebagai perwujudan perasaan dan sikap tidak puas terhadap pendidikan yang telah diterimanya dan sebagai pernyataan dan kesadaran terhadap perkembangan dan kemajuan bidang tugasnya yang harus diikuti sejalan dengan kemajuan ilmu pengetahuan dan teknologi, pengalaman profesional yang berharga mungkin diperoleh oleh guru yang berani dan selalu bersedia mewujudkan ide atau gagasan dan mengembangkan proses belajar mengajar di kelas dan di lingkungan sekitar.

Pembahasan tentang keprofesionalan guru saat ini masih banyak dibicarakan orang dan masih saja dipertanyakan orang baik kalangan para pakar maupun di luar kalangan para pakar pendidikan. Bahkan banyak yang cenderung melecehkan posisi guru. Orang tua siswa pun kadang mencemoohkan dan menuding guru kurang profesional, tidak berkualitas, ketika anaknya tidak dapat menyelesaikan persoalan yang ia hadapi sendiri atau memiliki kemampuan yang tidak sesuai dengan keinginannya.

Permasalahan yang dihadapi oleh masyarakat terhadap profesi guru kurang berkenan berbeda dengan pengakuan profesi dokter atau hakim . Apabila ukuran tinggi rendahnya pengakuan keprofesionalan tersebut adalah keahlian dan tingkat pendidikan yang ditempuhnya, gurupun ada yang setingkat dengan profesi lain dan bahkan ada yang lebih baik.

Faktor lain yang mengakibatkan rendahnya pengakuan masyarakat terhadap profesi guru adalah kelemahan yang terdapat pada guru itu sendiri seperti rendahnya keprofesionalan guru, penguasaan guru dalam memotivasi belajar siswa serta kemampuan-kemamuan lain yang belum optimal. 


\section{Pengertian Profesionalisme Guru}

Istilah profesionalisme guru terdiri dari dua suku kata yang masing-masing mempunyai pengertian tersendiri, yaitu kata Profesionalisme dan Guru. Ditinjau dari segi bahasa (etimologi), istilah profesionalisme berasal dari Bahasa Inggris profession yang berarti jabatan, pekerjaan, pencaharian, yang mempunyai keahlian ${ }^{2}$, sebagai mana disebutkan oleh S. Wojowasito. Selain itu, Drs. Petersalim dalam kamus bahasa kontemporer mengartikan kata profesi sebagai bidang pekerjaan yang dilandasi pendidikan keahlian tertentu ${ }^{3}$.

Dengan demikian kata profesi secara harfiah dapat diartikan dengan suatu pekerjaan yang memerlukan keahlian dan ketrampilan tertentu, dimana keahlian dan ketrampilan tersebut didapat dari suatu pendidikan atau pelatihan khusus. Sedangkan pengertian profesional itu sendiri berarti orang yang melakukan pekerjaan yang sudah dikuasai atau yang telah dibandingkan baik secara konsepsional, secara teknik atau latihan ${ }^{4}$.

Dari beberapa pengertian diatas ini mengambarkan bahwa tidak semua profesi atau pekerjaan bisa dikatakan profesional karena dalam tugas profesional itu sendiri terdapat beberapa ciri-ciri dan syarat-syarat sebagaimana yang dikemukakan oleh Robert W. Riche, yaitu:

a. Lebih mementingkan pelayanan kemanusiaan yang ideal dibandingkan dengan kepentingan pribadi.

b. Seorang pekerja profesional, secara relatif memerlukan waktu yang panjang untuk mempelajari konsep- konsep serta prinsip- prinsip pengetahuan khusus yang mendukung keahliannya.

c. Memiliki kualifikasi tertentu untuk memasuki profesi tersebut serta mampu mengikuti perkembangan dalam pertumbuhan jabatan.

d. Memiliki kode etik yang mengatur keanggotaan, tingkah laku, sikap dan cara kerja.

e. Membutuhkan suatu kegiatan intelektual yang tinggi.

f. Adanya organisasi yang dapat meningkatkan standar pelayanan, disiplin diri dalam profesi, serta kesejahteraan anggotanya.

2 S. Wojowasito, WJS. Poerwadarminto, Kamus Bahasa Inggris Indonesia-Indonesia Inggris (Bandung: Hasta, 1982), 162.

${ }^{3}$ Salim, Yeny salim, Kamus Indonesia Kontemporer, Moderninglish (Jakarta: Pres, 1991), 92.

${ }^{4}$ Sadirman A. M, Interaksi dan Motifasi Belajar (Jakarta: Rajawali Pres,1991), 131. 
g. Memberikan kesempatan untuk kemajuan, spesialisasi dan kemandirian.

h. Memandang profesi sebgai suatru karier hidup (a live career) dan menjadi seorang anggota permanen ${ }^{5}$.

Sedangkan pengertian guru seperi yang telah dikemukakan oleh beberapa ahli sebagai berikut;

a. Drs. Petersalim dalam kamus bahasa Indonesia Kontemporer mengartikan guru adalah orang yang pekerjaanya mendidik, mengajar, dan mengasihi, sehingga seorang guru harus bersifat mendidik ${ }^{6}$.

b. Ahmad D. Marimba, menyatakan bahwa guru adalah orang yang mempunyai tanggung jawab untuk mendidik ${ }^{7}$.

c. Amien Daiem Indrakusuma menyatakan bahwa guru adalah pihak atau subyek yang melakukan pekerjaan mendidik ${ }^{8}$.

d. M. Athiyah Al Abrasyi menyatakan bahwa guru adalah spiritual father atau bapak rohani bagi seorang murid, memberi santapan jiwa, pendidikan akhlak dan membenarkannya, meghormati guru itulah mereka hidup dan berkembang'

Dari pendapat para ahli diatas maka pengertian guru sebagaimana yang dikemukakan, diatas maka secara umum dapat diartikan bahwa guru adalah orang yang bertanggung jawab terhadap perkembangan seluruh potensi anak didik, baik potensi afektif, potensi kognitif, maupun potensi psikomotor.

Dari beberapa pengertian atau definisi "profesionalisme" dan "guru" diatas dapat ditarik suatu pengertian bahwa profesionalisme guru mempunyai pengertian suatu sifat yang harus ada pada seorang guru dalam menjalankan pekerjaanya sehingga guru tersebut dapat menjalankan pekerjannya dengan penuh tanggung jawab serta mampu untuk mengembangkan keahliannya tanpa menggangu tugas pokok guru tersebut.

\section{Tugas dan Tanggung Jawab Guru}

Tugas dan tanggung jawab guru sebenarnya bukan hanya disekolah atau madrasah saja, tetapi bisa dimana saja mereka berada. Dirumah, guru sebagai orang tua dari anak mereka adalah pendidik bagi putera-puteri mereka. Didalam masyarakat desa tempat tinggalnya, guru sering dipandang sebagai tokoh teladan bagi orang-

${ }^{5}$ M. Arifin, Kapita Selekta Pendidikan Islam dan Umum (Jakarta: 1993), 105.

${ }^{6}$ Salim, Yeny Salim.op.cit, 492.

${ }^{7}$ Ahmad D. Marimba, Pengantar Filsafat Pendidikan Islam (Bandung: Al Maarif, 1980), 37.

${ }^{8}$ Amien Daiem Indrakusuma, Pengantar Ilmu Pendidikan (Surabaya:Usaha Nasional, 1993), 179.

${ }^{9}$ M. Athiyah Al Abrasy, Dasar-Dasar Pokok Pendidikan Islam (Jakarta: Bulan Bintang, 1979), 136. 
orang disekitarnya. Pandangan, pendapat, atau buah fikirannya sering menjadi ukuran atau pedoman kebenaran bagi orang-orang disekitarnya karena guru dianggap memiliki pengetahuan yang lebih luas dan lebih mendalam dalam berbagai hal.

Adapun tugas pokok seorang guru dalam kedudukannya sebagai pendidik professional atau tenaga pendidik seperti disebutkan dalam UU RI No.20 tahun 2003 pasal 39 tentang Sistem Pendidikan Nasional menyebutkan:

1) Tenaga kependidikan bertugas melaksanakan administrasi, pengelolaan, pengembangan, pengawasan, dan pelayanan teknis untuk menunjang proses pendidikan pada satuan pendidikan.

2) Pendidik merupakan tenaga professional yang bertugas merencanakan dan melaksanakan proses pembelajaran, menilai hasil pembelajaran, melakukan penelitian, dan pengabdian kepada mayarakat, terutama bagi pendidik pada perguruan tinggi.

3) Pendidik yang mengajar pada satuan pendidikan dasar dan menengah disebut guru dan pendidik yang mengajar pada satuan pendidikan tinggi disebut dosen. ${ }^{10}$ b. Tugas personal guru

Guru merupakan ujung tombak dalam proses belajar mengajar didalam kelas. Oleh karena itu kemampuan guru marupakan indikator pada keberhasilan proses belajar mengajar. Disamping itu tugas profesionalisme guru juga mencakup tugas terhadap diri sendiri, terhadap keluarga, dan terutama tugas dalam lingkungan masyarakat dimana guru tersebut tinggal. Tugas-tugas tersebut tidak dapat dipisahkan dari kehidupan seorang guru, karena bagaimanapun juga sosok kehidupan seorang guru adalah merupakan sosok utama yang berkaitan dengan lingkungan dimana guru tinggal, sehingga guru harus mempunyai pribadi yang rangkap yang harus dapat diperankan dimana guru itu berada. Tugas personal guru yang dimaksud disini adalah tugas yang berhubungan dengan tanggungjawab pribadi sebagai pendidik, dirinya sendiri dan konsep pribadinya.

Tugas guru yang berhubungan dengan tanggung jawab sebagai seorang pendidik, sangat erat hubungannya dengan tugas profesionalisme yang harus dipenuhi oleh seorang guru dalam kaitannya dengan pelaksanaan proses belajar mengajar. Dewasa ini sering dijumpai bahwa seorang guru lebih mementingkan tugas pribadinya dari pada harus melaksanakan tugas dan kewajibannya sebagai seorang

${ }^{10}$ Undang-Undang Republik Indonesia, Sistem Pendidikan Nasional (Bandung: Citra Umbara, 2003), 27. 
pendidik, sehingga tidak mustahil adanya guru yang tidak bisa melaksanakan tugasnya sebagai pendidik dengan baik, karena lebih mementingkan persoalan yang berkenaan dengan pribadinya sendiri. Misalnya seorang guru tidak mengajar karena harus mengajar ditempat lain untuk menambah pendapatan pribadinya. Hal semacam ini seringkali mengakibatkan jatuhnya korban pada salah satu pihak, yaitu anak didiknya, hal ini dikarenakan keteledoran guru yang berusaha mencari tambahan penghasilan untuk dirinya pribadi.

Kenyataan diatas, menunjukkan bahwa sering kali guru tidak dapat memisahkan antara tanggung jawab sebagai seorang pendidik dan kepentingan pribadinya, karena itu seorang guru harus mengetahui peran dan tanggung jawab pekerjaan yang diembannya. Hal ini sesuai dengan apa yang dikemukakan oleh DR. Zakiah Darajat, bahwa setiap guru hendaknya mengetahui dan menyadari betul bahwa kepribadiannya yang tercermin dalam berbagai penampilan itu ikut menentukan tercapai tidaknya tujuan pendidikan pada umumnya, dan tujuan lembaga pendidikan tempat ia mengajar khususnya ${ }^{11}$.

Pernyataan tersebut mengandung pengertianbahwa seorang guru dituntut untuk memiliki kepribadian yang mantap dalam menjalankan tugas dan tanggung jawabnya sebagai pendidik pada umumnya, ataupun citra dirinya yang menyandang predikat sebagai seorang guru.

c. Tugas sosial guru

Tugas sosial bagi seorang guru ini berkaitan dengan komitmen dan konsep guru dalam masyarakat tentang peranannya sebagai anggota masyarakat dan sebagai pembaharu pendidikan dalam masyarakat. Secara langsung maupun tidak langsung tugas tersebut harus dipikul dipundak guru dalam meningkatkan pembangunan pendidikan masyarakat.

Argumentasi sosial yang masih timbul dalam masyarakat adalah menempatkan kedudukan guru dalam posisi yang terhormat, yang bukan saja ditinjau dari profesi atau jabatannya, namun lebih dari itu merupakan sosok yang sangat kompeten terhadap perkembangan kepribadian anak didik untuk menjadi manusiamanusia kader pembangunan. Hal ini sesuai dengan apa yang dikemukakan oleh Ali Saifulloh H.A. dalam bukunya "Antara Filsafat dan Pendidikan" yang mengemukakan bahwa argumentasi sosial ini melihat guru bukan hanya sebagai

11 Zakiah Darajat, Ilmu Pendidikan Islam (Jakarta: Bumi Aksara, 1992), 19. 
pengajar, tetapi adalah sebagai pendidik masyarakat sosial lingkungannya disamping masyarakat sosial profesi kerjanya sendiri ${ }^{12}$.

Dari pernyataan diatas dapat dipahami bahwa tugas sosial guru tidak hanya sebagai pendidik masyarakat keluarganya, tetapi juga masyarakat sosial lingkungannya serta masyarakat sosial dari profesi yang disandangnya. Dengan perkataan lain, potret dan wajah bangsa dimasa depan tercermin dari potret-potret diri para guru dewasa ini. Dengan gerak maju dinamika kehidupan bangsa berbanding lurus dengan citra para guru ditengah-tengah masyarakat ${ }^{13}$.

Hal tersebut membuktikan bahwa sampai saat ini masyarakat masih menempatkan guru pada tempat yang terhormat dilingkunganya dan juga dalam kiprahnya untuk mensukseskan pembangunan manusia seutuhnya. Karena dari guru diharapkan masyarakat dapat memperoleh ilmu pengetahuan, dan hal ini mempunyai arti bahwa guru mempunyai kewajiban mencerdaskan kehidupan bangsa menuju kepada pembentukan manusia Indonesia seutuhnya berdasarkan Pancasila. Bahkan pada hakikatnya guru juga merupakan komponen strategis yang memiliki peran penting dalam menentukan gerak majunya kehidupan suatu bangsa.

Melihat dari beberapa uraian diatas, maka dapat digaris bawahi dalam masyarakat tidak ada pejabat lain yang memikul tanggung jawab moral begitu besar selain guru dengan segala konteks dari lingkupnya. Hal ini sesuai dengan apa yang telah disinyalir oleh Tim Pembina Matakuliah Didaktik Metodik atau Kurikulum yang menyatakan bahwa, naik turunnya martabat suatu bangsa terletak pula sebagaian besar dipundak para guru atau pendidik formal yang bertugas sebagai pembina generasi masyarakat yang akan datang. Guru dan pendidikan non formal lainnya adalah pemegang kunci dari pembangunan bangsa atau "Nation and character building". Karena itulah dalam hati sanubari setiap guru harus selalu berkobar semangat" ${ }^{\prime 14}$.

Ungkapan tersebut menunjukkan bahwa tugas dalam lingkungan sosial kemasyarakatan,seorang guru bukan saja harus menjadi panutan dan contoh bagi anak didiknya namun juga menjadi cermin masyarakat, terutama dalam upayanya mempersiapkan generasi muda penerus pembangunan dewasa ini. Hal ini sangat penting karena dari gurulah diharapkan nilai-nilai pengetahuan ynag bersifat edukatif maupun normatif dapat diwariskan kepada generasi penerus bangsa. Hal ini juga

12 Ali Saifullah, Antara Filsafat dan Pendidikan (Surabaya: Usaha Nasional, 1989), 12-13.

13 Moh. Uzer Usman, Menjadi Guru Profesiona, (Bandung: Remaja Rosda Karya.. 1994), 15.

14 Tim Pembina Matakuliah Didakdik Metodik, Kurikulum PBM (Surabaya: IKIP Surabaya, 1981), 9. 
sesuai dengan apa yang diperintahkan oleh Nabi Muhammad SAW, dalam suatu hadist yang artinya "Didiklah anak-anakmu, mereka itu dijadikan buat menghadapi masa yang lain dari masa kamu nanti ${ }^{15}$.

\section{Kemampuan Profesional Guru}

Kemampuan, keahlian atau sering disebut dengan kompetensi profesional guru sebagaimana dikemukakan oleh Piet A. Sahartian dan Ida Aleida adalah sebagai berikut: "Kompetensi profesional guru yaitu kemampuan penguasaan akademik (mata pelajaran yang diajarkan) dan terpadu dengan kemampuan mengajarnya sekaligus sehingga guru itu memiliki wibawa akademis"16.

Kompetensi profesional yang dimaksud adalah kemampuan guru untuk menguasai masalah akademik yang sangat berkaitan dengan pelaksanaan proses belajar-mengajar, sehingga kompetensi ini mutlak dimiliki guru dalam menjalankan tugasnya sebagai pendidik dan pengajar. Para pakar dan ahli pendidikan mengemukakan bahwa kompetensi guru merupakan salah satu syarat yang pokok dalam pelaksanaan tugas guru dalam jenjang apapun.

Adapun kompetensi profesional yang dikembangkan oleh proyek pembina pendidikan guru adalah sebagaimana yang telah dikemukakan oleh Nana Sujdana sebagai berikut:

a. Menguasai bahan

b. Mengelola program belajar mengajar.

c. Mengelola kelas.

d. Mengunakan media atau sumber belajar.

e. Menguasai landasan pendidikan.

f. Mengelola interaksi belajar-mengajar.

g. Menilai prestasi belajar-mengajar.

h. Mengenal fungsi bimbingan dan penyuluhan.

i. Mengenal dan meyelenggarakan admistrasi sekolah.

j. Memahami dan menafsirkan hasil penelitian guna keperluan pengajaran ${ }^{17}$.

15 M. Athiyah Al-Abrosyi, Dasar-Dasar Pokok Pendidikan Islam (Jakarta: Bulan Bintang, 1979), 35.

16 Piet A.Sahertian, Super Visi Pendidikan Dalam Rangka Program Inservice Eduacatio (Surabaya:.Usaha Nasional, 1990), 32 .

${ }^{17}$ Nana Sudjana Dasar-dasar Proses Belajar Mengajar (Bandung: Sinar Baru, 1991), 20. 
Dari kompetensi tersebut jika ditelaah secara mendalam maka hanya mencakup dua bidang kompetensi yang pokok bagi guru, yaitu kompetensi kognitif dan kompetensi perilaku.

Untuk analisis guru sebagai pengajar maka kemampuan guru atau kompetensi guru yang banyak hubunganya dengan usaha meningkatkan proses dan hasil belajar dapat digolongkan kedalam empat kemampuan, yaitu:

a. Merencanakan program belajar-mengajar.

b. Melaksanakan dan memimpin atau mengelola proses belajar-mengajar.

c. Menilai kemajuan proses belajar-mengajar.

d. Menguasai bahan pelajaran yaitu bidang studi atau mata pelajaran yang dipegangnya ${ }^{18}$.

Kemampuan-kemampuan yang disebutkan dalam empat hal tersbut adalah merupakan kemampuan yang sepenuhnya harus dikuasai guru yang bertaraf profesional. Untuk mempertegas dan memperjelas kemampuan tersebut, akan dibahas sebagi berikut:

a. Kemampuan merencanakan program belajar mengajar.

Sebelum merencanakan belajar mengajar guru perlu terlebih dahulu mengetahui arti dan tujuan perencanaan tersebut dan secara teoritis dan praktis unsur-unsur yang terkandung didalamnya, adapun makna dari perencanaan program balajar mengajar adalah sauatu proyeksi atau perkiraan guru mengenai kegiatan yang harus dilakukan oleh siswa selama pengajaran itu berlangsung dan tujuannya adalah sebagai pedoman guru dalam melaksanakan praktek atau tindakan mengajar guru dalammeencanakan program belajar mengajar meliputi:

1) Merumuskan tujuan instruksional

2) Mengenal dan mengunakan metode mengajar

3) Memilih dan menyusun prosedur intruksional yang tepat.

4) Melaksanakan program belajar mengajar.

5) Mengenal kemampuan (entre bebaviour) anak didik merencanakan dan melaksanakan penelitian ${ }^{19}$.

b. Melaksanakan kegiatan belajar mengajar.

18 Ibid, 20.

${ }_{19}$ Moh. Uzer Usman, Menjadi Guru Profesional (Bandung: Rosda Karya, 1989), 35. 
Peningkatan Keprofesionalan Guru Dalam Pembelajaran Pendidikan Agama Islam di MTs Arrohmaniyah NW Senyiur

Dalam proses belajar mengajar ini kegiatan yang harus dilaksanakan adalah menumbuhkan dan menciptakan kegiatan siswa sesuai dengan rencana yang telah disusun. Adapun yang termasuk dalam pengelolaan proses belajar mengajar meliputi prinsip-prinsip mengajar, keterampilan menilai hasil belajar siswa, penggunaan alat bantu, ketrampilan memilih, dan mengunakan strategi atau pendekatan mengajar. Dan kemampuan ini dapat diperoleh melalui pengalaman langsung ${ }^{20}$.

c. Menilai kemampuan proses belajar mengajar.

Dalam menilai kemampuan dan kemajuan proses belajar mengajar guru harus dapat menilai kemajuan yang dicapai oleh siswa yang meliputi bidang afektif dan kognitif serta psikomotorik. Kemampuan penilaian ini dapat dikatakan dalam dua bentuk yang dilakukan melalui pengamatan terus menerus tentang perubahan kemajuan yang dicapai siswa. Sedangkan penilaian dengan cara pemberian skor angka atau nilai yang bisa dilakukan dalam rangka penilaian hasil belajar siswa.

d. Menguasai bahan pelajaran.

Secara jelas konsep yang harus dikuasai oleh guru dalam penguasaan bahan pelajaran ini telah tertuang dalam kurikulum khususnya Garis-garis Besar Program Pengajaran (GBPP) yang disajikan dalam bentuk Pokok Bahasan dan Sub-Pokok Bahasan. Dan uraiannya secara mendalam dituangkan dalam bentuk buku paket dari bidang studi yang bersangkutan.

Dari beberapa uraian diatas menunjukkan betapa pentingnya penguasaan kompetensi bagi seorang guru yang profesional, karena hal tersebut sangat berpengaruh dalam upaya meningkatkan mutu pendidikan itu sendiri.

Proses Belajar Mengajar

\section{Pengertian Proses Belajar Mengajar}

Dalam dunia pendidikan kita mengenal istilah Proses Belajar Mengajar (PBM) yang didalamnya terkandung variabel-variabel pokok berupa kegiatan guru dalam mengajar dan kegiatan murid dalam belajar. Menurut Benyamin S. Blom dalam bukunya The Taxonomy of Educational Objectives-Cognitive Domain, menyebutkan bahwa dengan Proses Belajar Mengajar kita akan memperoleh kemampuan yang terdiri dari tiga aspek adalah aspek pengetahuan, aspek sikap, dan aspek ketrampilan ${ }^{21}$.

${ }^{20}$ Nana Sudjana. Op. Cit, 21.

21 Prof. Dr. Nasution, MA, Teknologi Pendidikan (Bandung: Jenmers, 1962), 34. 
Aspek pengetahuan berhubungan dengan kemampuan individual mengenai dunia sekitarnya yang meliputi perkembangan intelektual atau mental. Aspek sikap mengenai perkembangan sikap, perasaan, nilai-nilai yang dahulu sering disebut sebagai perkembangan emosionalatau moral, sedangkan aspek ketarampilan menyangkut perkembangan ketrampilan yang mengandung unsur motoris.

Ketiga aspek itu secara sederhana dapat dipandang sebagai aspek yang bertalian dengan "head" (aspek cognitive), "heart" (aspek affective), dan "hand" (aspek psychomotor), ayang ketiganya saling berhubungan erat, tidak terpisah satu dengan yang lain.

Dari penjelasan diatas dapat diperoleh kejelasan bahwa proses belajarmengajar pada dasarnya mengharapkan terjadinya perubahanmasing-masing aspek tersebut, hanya tingkat kedalaman perubahan masing-masing aspek harus disesuaikan dengan disiplin ilmu yang dipelajarinya. Namun yang jelas diharapkan bahwa dengan perubahan yang terjadi dalam tiga aspek tersebut akan berpengaruh terhadap tingkah laku murid ${ }^{22}$. Dimana pada akhirnya cara, cara merasa, dan cara murid melakukan sesuatu itu akan menadi relatif menetap dan membentuk kebiasaan bertingkah laku pada dirinya. Segala sesuatu yang dipelajarinya hendaknya merupakan satau landasan bagi dirinya untuk melakukan usaha-usaha pemecahan teradap masalah-masalah yang dihadapinya dikemudian hari. Hal ini berarti bahwa perubahan yang terjadi pada dirinya harus merupakan perubahan tingkah laku yang lebih baik.

Berdasarkan penjelasan diatas, dapat disimpulkan bahwa proses belajar mengajar merupakan suatu proses yang mengakibatkan beberapa perubahan yang relatif menetap dalam tingkah laku seseorang.Sesuai dengan tujuan pendidikan yang dikemukakan oleh Bloom, maka sifat perubahan yang terjadi pada masing-masing aspek itupun bergantung ada tingkat kedalaman belajar-mengajar yang dialami.

2. Ciri dan Pola Interaksi Proses Belajar Mengajar

Proses Belajar Mengajar sering disebut juga dengan Kegiatan Belajar mengajar, yang didalamnya terkandung dua unsur pokok, yaitu: unsur kegiatan guru dan unsur kegiatan murid. Dalam proses mengajar yang sering juga disebut prosedur mengajar, guru melakukan kegiatan atau perbuatan yang betujuan membawa anak kearah tujuan, dan anak didik melakukan kegiatan yang disediakan oleh guru, yaitu kegiatan belajar yang juga bertujuan pada tujuan yang sama. Sehingga apa yang akan

22 Ibid, 35 . 
dilakukan guru akan mendapat respon dari murid, dan apa yang dilakukan murid akan mendapat sambutan dari guru. Semua kegiatan tersebut sekurang-kurangnya harus terdapat: 1). Tujuan yang jelas, 2). Bahan yang menjadi isi interaksi, 3). Pelajar yang aktif mengalami, 4). Guru yang melaksanakan, 5). Metode tertentu untuk mencapai tujuan, 6). Situasi yang memungkinkan terjadinya proses interaksi, 7). Penilaian terhadap hasil interaksi ${ }^{23}$

Dari komponen-komponen diatas, tanpa mengurangi pentingnya komponen lain, komponen guru merupakan komponen yang paling menentukan dalam proses belajar mengajar. Untuk itu kualifikasi guru sangat penting diperhatikan dalam rangka pencapaian tujuan pendidikan dengan prestasi belajar murid sebagai salah satu indikatornya.

\section{Beberapa Faktor Yang Mempengaruhi Proses Belajar Mengajar}

Agar perubahan-perubahan dalam diri anak didik sebagai hasil dari suatu proses belajar mengajar itu sampai pada tujuan yang diharapkan, perlu diperhatikan faktor-faktor apa saja yang mempengaruhi proses belajar-mengajar tersebut.

Fakor-faktor tersebut diantaranya, murid yang merupakan bahan baku dan yang harus diberi pengarahan dalam proses belajar mengajar, proses belajar mengajar itu sediri sebagai usaha untuk mempengaruhi murid. Dalam proses belajar itu juga terdapat faktor-faktor yang dengan disengaja direncanakan dan dimanipulasi untuk menunjang tercapainya keluaran yang dikehendaki.

Faktor-faktor yang mempengaruhi proses belajar-mengajar yang ada pada murid dapat dibagi menjadi dua, yaitu: (1)dari luar, seperti: kurikulum, sarana, pengajar, program belajar, sosial, dan lingkungan murid, dan (2) dari dalam murid sendiri, seperti: kondisi fisik, indera, minat, kecerdasan, motivasi, ingatan, perhatian, dan sikap.

\section{Fungsi Tujuan Dalam Proses Belajar Mengajar}

Sebagaimana diketahui bahwa belajar mengajar adalah suatu kegiatan bertujuan, dengan pengertian kegiatan yang terikat oleh tujuan, terarah pada tujuan, dan dilaksanakan untuk mencapai tujuan. dengan demikian merumuskan tujuan yang akan dicapai adalah merupakan aspek terpenting yang harus diperhatikan guru dalam mengajar.

23 Prof. Dr. W. Surakhmad, Pengantar Interaksi Mengajar Belajar, (Bandung: Tarsito, 1980), 16. 
Taraf pencapaian tujuan pengajaran pada hakikatnya adalah merupakan petunjuk praktis tentang sejauh manakah proses belajar mengajar itu harus dibawa untuk mencapai tujuan yang terakhir. Hal yang demikian berlaku umum bauk dalam pendidikan keluarga maupun pendidikan sosial masyarakat, organisasi dan sekolah.

Setuap cabang pendidikan mempunyai pedoman umum tentang tujuan akhur yang akan dicapai. Tujuan pendidikan sebagai peraturan perindang-undangan.seperti di Indonesia telah ditetapkan dasar, tujuan,dan sistem pendidikan nasional.dari peraturan perundang-undangan itu diperinci ketentuan-ketentuan bagi tujuan bagi lembaga-lembaga pendidikan tertentu.

Dalam hal ini diperlukan cara kerja yang efektif dan efisien,agar semua tujuan dapat tercapai. Salah satu cara yang telah diwujudkan dalam bentuk organisasi organisasi dan pengaturannya yang fundamental dan sistematis adalah berupa sistem penilaian atau evaluasi. Evaluasi ini digunakan ntuk mencapai tujuan baik dari murid maupun dari fihak guru. Dengan pengetuan lal bahwa evaluasi mempunyai arti diagnostik, yakni mencari dan menetapkan sebab-sebab kegagalan untuk diadakan perubahan dan perbaikan sehingga tidak semata-mata menentikan lulus atau tidak lulus.

Hubungan evaluasi/penilaian dengan seluruh proses belajar mengajar terlihat pada langkah-langkah beriku :

1. menetapkan tujuan yang hendak dicapai

2. mempersiapkan pengalaman dan kegiatan yang dapat digunakan untuk mencapai tujuan.

3. menilai dengan yakin bahwa hasil yang diharapkan dapat tercapai.

Untuk dapat menjadikan tujuan tertentu sebagai petunjuk operasional, diperlukan rumusan tujuan secara lebih khusus. Rumusan tujuan harus dipusatkan pada perubahan tingkah laku anak didik. Dan selanjutnya menempatkan tujuan fungsional sebagai tujuan akhir.

\section{Beberapa Tingkatan Proses Belajar}

Kelancaran anak untuk belajar sebenarnya tergantung dari efisiensi mekanisme penerimaan dan tanggapannya. Setiap anak didik akan memberikan tanggapan yang baik sejauh apa yang dibahas guru mempunyai hubungan dengan pengalaman yang dimilikinya. Tanggapan juga merupakan dasar dari pembentukan sikap. Dengan pembentukan sikap ini (sebagai hasil belajar) berlangsung dengan 
saling berkaitan satu sama lain. Berkaitan dengan ini, ada delapan tingkatan proses belajar mengajar, yaitu:

1. Tingkat pengolahan informasi, yaitu kegiatan yang dilakukan oleh guru untuk mengolah informasi seperti pembuatan Tujuan Intruksional Khusus, metode, serta media yang digunakan.

2. Tingkat penyampaian informasi, yaitu kegiatan guru untuk menyampaiakn informasi tentang tujuan pembelajaran kepada murid.

3. Tingkat penerimaan informasi, yaitu kegiatan penerimaan informasi yang diberikan oleh guru kepada murid.

4. Tingkat pengolahan informasi, yaitu kegiatan murid untuk meninterpretasikan informasi yang telah diberikan oleh guru dengan cara berpikir dan menyimpulkan persoalan-persoalan yang menjadi dasar untuk menetapkan tindakan.

5. Tingkat respon dari anak didik, yaitu respons dari peserta didik terhadap informasi dari guru.

6. Tingkat diagnosis dari guru, yaitu kegiatan mengamati yang dilakukan oleh guru terhadap perubahan yang terjadi pada anak didik

7. Tingkat evaluasi guru, yaitu kegiatan guru mengevaluasi kualitas dan tingkat belajar anak didik dengan membandingkan tingkah laku anak dengan tujuan pembelajaran.

8. Tingkat penyampaian "tahu-hasil" kepada anak didik, tanggapan yang dilakukan guru terhadap tingkah murid sebagai informasi timbal balik terhadap semua tingkah laku siswa yang dapat dilakkann dengan kata-kata, anggukan, gerakan , dan lain-lain.

\section{Metode penelitian}

\section{Rancangan Penelitian}

Penelitian ini menggunakan rancangan penlitian dengan pendekatan deskriptif kualitatif. Pendekatan deskriptif kualitatif merupakan penelitian yang didasarkan pada data alamiah yang berupa kata-kata dalam mendeskripsikan obyek yang diteliti. Pendekatan deskriptif kualitatif berusaha mengungkapkan gejala secara holistik-kontekstual (secara utuh sesuai dengan konteks) melalui kegiatan pengumpulan data dari latar yang alami.

\section{Pendekatan Penelitian}


Penelitian ini menggunakan pendekatan kualitatif sebagai prosedur penelitian yang menghasilkan data deskriptif dan berupa kata-kata tertulis. Dengan demikian, laporan penelitian akan berisi kutipan-kutipan data untuk memberikan gambaran penyajian laporan tersebut ${ }^{24}$.

Pendekatan deskriptif kualitatif sebagai prosedur penelitian karena dalam penelitian ini peneliti hanya mendeskripsikan, menjelaskan, memaparkan, menuliskan serta melaporkan suatu keadaan obyek atau data yang telah diperoleh dari sumber data. Tujuan pendekatan penelitian ini adalah untuk melukiskan variabel atau kondisi yang ada dalam suatu situasi.

\section{Data dan Sumber Data}

Jenis data yang berupa data verbal dalam penelitian kualitatif hanya berwujud kata-kata bukan angka. Data kualitatif merupakan sumber deskripsi yang luas dan berlandasan kokoh, serta memuat penjelasan tentang proses-proses yang terjadi dalam lingkup tertentu.

Sumber data dalam penelitian ini adalah subyek dimana data diperoleh. Dalam penelitian ini penulis menggunakan kuesioner atau wawancara dalam pengumpulan datanya, maka sumber data disebut responden yaitu orang-orang yang merespon dan menjawab pertanyaan-pertanyaan peneliti. Yang menjadi sumber data dalam penelitian ini adalah kepala sekolah dan guru pendidikan agama islam

\section{Instrumen Penelitian}

Kedudukan peneliti dalam penelitian ini adalah sebagai instrumen. Selain itu peneliti juga sebagai perencana, pelaksana pengumpulan data, analisis, penafsir data, dan pada akhirnya ia menjadi pelapor hasil penelitiannya. Dalam penelitian kualitatif, tidak ada pilihan lain daripada menjadikan manusia sebagai instrumen penelitian utama. Alasannya ialah bahwa, segala sesuatunya belum mempunyai bentuk yang pasti. Masalah, fokus penelitian, prosedur penelitian, hipotesis yang digunakan, bahkan hasil yang diharapkan, itu semuanya tidak dapat ditentukan secara pasti dan jelas sebelumnya. Segala sesuatu masih perlu dikembangkan sepanjang penelitian.

Selama dalam penelitian, peneliti sebagai alat satu-satunya yang dapat mencapainya dan kehadiran peneliti semakin memudahkan dalam menggali informasi sebanyak-banyaknya.

\section{Teknik Pengumpulan Data}

${ }^{24}$ Arif Furqon, Pengantar penelitian dalam Pendidikan, (Surabaya: Usaha Nasional, 1982), 415. 
Teknik pengumpulan data yang digunakan dalam penelitian ini adalah observasi, dokumentasi dan wawancara.

a) Observasi

Observasi adalah metode yang menggunakan cara pengamatan dan pencatatan secara sistematis terhadap fenomena-fenomena yang diselidiki ${ }^{25}$.Observasi yang berarti mengamati bertujuan untuk mendapat data tentang suatu masalah sehingga diperoleh pemahaman atau sebagai alat pembuktian atau keterangan yang diperoleh sebelumnya.

b) Wawancara

Menurut Lexy J Moleong, wawancara adalah percakapan dengan maksud tertentu. Percakapan itu dilakukan oleh dua pihak yaitu pewawancara yang mengajukan pertanyaan dan yang diwawancarai yang memberikan jawaban atas pertanyaan $i^{26}$.

Wawancara ini digunakan untuk mengumpulkan data dengan jalan tanya jawab sepihak dengan sumber data, yang dikerjakan dengan sistematik dan berlandaskan pada tujuan penelitian. Dengan menggunakan metode ini akan dapat dikumpulkan data representatif dari seluruh pihak yang terkait mengenai peningkatan keprofesionalan guru dalam pembelajaran di MTs Arrohmaiyah NW Senyiur c) Dokumentasi

Menurut Suharsimi Arikunto, metode dokumentasi adalah mencari data mengenai hal-hal yang variable yang berupa catatan, transkip, buku, surat kabar, majalah, prasasti, notulen rapat, leger, agenda dan sebagainya ${ }^{27}$. Berdasarkan pengertian tersebut dapat diambil kesimpulan bahwa metode dokumentasi adalah pengumpulan data dengan meneliti catatan-catatan penting yang sangat erat hubungannya dengan obyek penelitian.

Dokumentasi ini digunakan untuk memperoleh data mengenai keadaan dan kondisi guru, baik ditinjau dari segi pengalaman pendidikan yang ditempuh maupun darni segi penggunaan sarana dan prasarana pendidikan serta penerapan pembelajaran.

\section{Triangulasi}

25 Sutrisno Hadi, Metodologi Penelitian Research II, (Yogyakarta: Andi Offset, 1990), hlm: 136

${ }^{26}$ Lexy Moleong, OpCit, 135.

27 Suharsimi Arikunto, Prosedur Penelitian Suatu Pendekatan Praktek, (Jakarta: Rineka Cipta, 1998), 188. 
Pengecakan kebenaran data atau informasi kegiatan ini disebut triangulasi yakni usaha mengecek kebenaran data atau informasi yang telah dikumpulkan. Usaha pertama yang dapat dilakukan yaitu membacakan kembali catatan jawaban untuk didengar oleh nara sumber. Usaha ini dilakukan pada saat akan mengakhiri kegiatan wawancara.

Triangulasi sangat diperlukan apabila terdapat data yang bertentangan atau berbeda mengenai hal yang sama, dari dua atau lebih sumber data. Untuk itu harus dilakukan kegiatan menelusuri setiap data yang ditemui sampai tuntas. Kegiatan pengecekan dilakukan pada data yang tidak jelas, meragukan dan bahkan tidak dapat diterima kebenarannya oleh akal atau dirasa kurang wajar dan tidak mungkin triangulasi dilakukan dengan menambah sumber data dan mungkin pula melakukan wawancara dan observasi ulang pada sumber data yang sama. Triangulasi bermaksud juga mewujudkan prinsip penelitian kualitatif dalam mengumpulkan data sampai tuntas atau sampai pada tingkat jenuh redundancy.

\section{Analisis Data}

Menurut Sugiono, analisis data dalam penelitian kualitatif dilakukan sejak sebelum memasuki lapangan, selama di lapangan dan setelah selesai dilapangan. Data yang diperoleh kemudian dianalisa, analisa dalam penelitian ini akan dilakukan sejak dan setelah proses pengumpulan data. Hasil dari wawancara dan catatan lapangan akan dipaparkan secara tertulis sesuai dengan kategorisasi yang telah ditetapkan dan kemudian dianalisa.

\section{Profesionalitas guru dalam pembelajaran Pendidikan Agama Islam di MTs}

\section{Arrohmaniyah NW Senyiur}

Sebagaimana telah dikemukakan pada bab II tentang pembelajaran Pendidikan Agama Islam merupakan upaya untuk membelajarkan siswa agar dapat memahami, menghayati dan mengamalkan nilai-nilai Islam melalui kegiatan bimbingan, pengajaran atau latihan. Oleh karena itu, guru Pendidikan Agama Islam dituntut memiliki persyaratan tertentu dalam menjalankan tugas dan tanggung jawabnya dengan baik. Maksudnya, bahwa guru Pendidikan Agama Islam harus Sumber Daya Manusia yang telah dipersiapkan secara khusus sebagai tenaga pendidik dan pengajar materi Pendidikan Agama Islam atau mempunyai kualifikasi sebagai guru Pendidikan Agama Islam. 
Peningkatan Keprofesionalan Guru Dalam Pembelajaran Pendidikan Agama Islam di MTs Arrohmaniyah NW Senyiur

Berdasarkan hasil wawancara dengan Ibu Dra. sMufidah selaku guru agama pada hari Selasa tanggal 18 Juli 2006 pada jam 08.30 dan observasi serta diperkuat dengan dokumentasi dapat diketahui tentang pendidikan terakhir guru Agama di MTs Arrohmaniyah NW Senyiur yaitu S I. Karena mereka telah memiliki ijazah keguruan yang menjadi syarat dari profesi seorang guru. Hal ini menunjukkan bahwa guru Pendidikan Agama Islam telah memiliki kualifikasi yang tinggi sebagai guru Pendidikan Agama Islam yang mengajar di tingkat Sekolah Menengah Pertama.

Faktor lain yang ikut menentukan pembelajaran adalah pengalaman guru dalam mengajar. Guru yang masa kerjanya cukup lama memiliki pengalaman yang relatif banyak dibandingkan dengan guru yang baru mengajar. Selama menjadi guru, ia dapat menilai kemampuan sekaligus memperbaiki sehingga kemampuan yang dimikili juga semakin mantap. Hal tersebut tentu saja berkaitan untuk selalu meningkatkan kemampuannya.

Pengalaman mengajar yang dijalani oleh guru Pendidikan Agama Islam di MTs Arrohmaniyah NW Senyiur dapat diketahui dari hasil wawancara dengan ibu Dra. Mufidah selaku guru Pendidikan Agama pada hari Jum'at tanggal 21 Juli 2006 jam 09.00 yang mengatakan bahwa ia mengajar sejak tahun 1984 sedangkan Ibu Siti Fatimah mengajar sejak tahun 1988.

Berdasarkan data tersebut, dapat diketahui bahwa ia memiliki kesempatan untuk mengembangkan atau meningkatkan kualitasnya sehingga dapat menunjukkan tugas-tugas mengajar dengan lebih mantap dan memudahkan untuk meningkatkan kualitas yang telah dimilikinya. Frekuensi pengalaman guru mengajar tersebut, diimplementasikan terhadap kegiatan guru Pendidikan Agama Islam dalam mengajar dan mendidik siswa.

Seorang guru agama dalam melaksanakan tugasnya harus membuat perencanaan atau persiapan mengajar agar pengajaran dapat terarah pada pencapaian tujuan. Mengenai rencana pembelajaran, guru Pendidikan Agama Islam di MTs Arrohmaniyah NW Senyiur selalu membuat persiapan mengajar. Dalam hal ini Ibu Siti Fatimah, S. Pdi pada hari Jum'at mengatakan bahwa ia selalu membuat rencana pembelajaran dan silabus. Akan tetapi, dalam pembelajaran tidak selalu sesuai dengan rencana pembelajaran yang saya buat, karena kenyataan yang ada di dalam kelas tidak selalu sesuai dengan yang direncanakan. 
Hal ini menunjukkan bahwa semua guru di MTs Arrohmaniyah NW Senyiur sudah menyadari arti pentingnya persiapan mengajar bagi persiapan tujuan pengajaran karena dari pembuatan persiapan mengajar dapat diketahui penguasaan guru Pendidikan Agama Islam terhadap materi yang akan disampaikan, mengingat mata pelajaran dapat berkembang. Oleh karena itu, persiapan megajar dapat dijadikan pedoman pengajaran agar terarah dan tidak simpang siur dalam pencapaian tujuan.

Pelaksanaan tugas mengajar, guru Pendidikan Agama Islam harus dapat menegtahui berbagai metode mengajar dan dapat menggunakann semua metode dengan pokok bahasan yang diberikan dan situasi belajar yang ada. Untuk mengetahui yang digunakan oleh guru Pendidikan Agama Islam di MTs Arrohmaniyah NW Senyiur dapat diketahui dari hasil wawancara dengan Siti Fatimah, S. Pdi yang mengatakan bahwa guru Pendidikan Agama Islam di MTs Arrohmaniyah NW Senyiur menggunakan metode yang bervariasi, diantaranya adalah metode ceramah, metode drill, metode diskusi, metode demonstrasi dan lain-lain. Karena metode tersebut adalah metode yang baik dan cocok untuk manyampaikan materi pelajaran. Selain metode tersebut, guru juga menggunakan metode kerja kelompok, hal ini digunakan untuk mengukur atau mengetahui keaktifan dan kedisiplinan siswa dalam belajar.

Oleh karena itu, guru Pendidikan Agama Islam harus dapat menggunakan dan menguasai metode-metode tersebut, karena penggunaan metode yang tepat dan sesuai dengan situasi dan kondisi dapat menumbuhkan minat belajar siswa terhadap mata pelajaran yang diberikan oleh guru.

Sedangkan untuk menumbuhkan situasi interaksi yang baik antara guru dan siswa, seorang guru perlu menciptakan suasana belajar yang harmonis yang penuh dengan keakraban dan kekeluargaan. Berdasarkan hasil wawancara dengan Ibu Dra. Mufidah, bahwa untuk menumbuhkan inetraksi yang baik antara guru dan siswa adalah dengan penguasaan kelas dan kelas itu harus hidup serta dengan memberikan penjelasan bahwa agama itu tidak hanya untuk kehidupan di dunia saja tetapi juga di akhirat. Dengan demikian, siswa akan belajar dengan sungguh-sungguh dan akan mengamalkan materi yang sudah dipelajarinya dalam kehidupan sehari-hari.

Faktor lain yang tidak kalah pentingnya dalam pencapaian tujuan pembelajararan adalah evaluasi. Evaluasi berfungsi untuk mengukur tinggi rendahnya 
tingkat keberhasilan siswa terhadap proses pengajaran yang telah dilaksanakan oleh guru.

Evaluasi tersebut tidak hanya terbatas pada test semester, tetapi dapat dilakukan pada setiap pelaksanaan pengajaran dalam pembelajaran untuk mengetahui hasil belajar siswa. Berdasarkan hasil wawancara dengan Ibu Dra. Mufidah dan Ibu Siti Fatimah, S. Pdi dapat diketahui bahwa semua guru Pendidikan Agama Islam di MTs Arrohmaniyah NW Senyiur telah melaksanakan evaluasi pembelajaran. Pelaksanaan evaluasi pembelajaran ini sangat berpengaruh terhadap keberhasilan guru dalam pelaksanaan pengajaran, karena dari hasil evaluasi yang dilaksanakan guru Agama dapat diketahui taraf keberhasilan siswa terhadap materi yang telah diberikan.

Selanjutnya dengan memanfaatkan hasil penafsiran tersebut, guru Pendidikan Agama Islam dapat menentukan langkah pembelajaran selanjutnya. Pernyataan guru Pendidikan Agama Islam tentang pelaksanaan evaluasi didukung dengan hasil wawancara dengan Ibu Dra. Mufidah selaku guru Agama bahwa guru Agama di MTs Arrohmaniyah NW Senyiur biasanya mengadakan evaluasi pada setiap selesai satu pokok bahasan dan Ibu Siti Fatimah, S. Pdi mengadakan Tanya jawab kepada siswa jika akan memulai pembelajaran. Hal tersebut dimksudkan agar siswa selalu siap pada saat pembelajaran dimulai.

Sedangkan tanggung jawab dan komitmen guru Pendidikan Agama Islam di MTs Arrohmaniyah NW Senyiur terhadap tugasnya ditandai dengan sikap mereka apabila mereka berhalangan hadir untuk mengajar mereka selalu memberi tahu kepada Kepala Sekolah atau guru piket dan untuk tanggung jawabnya terhadap siswa mereka memberi tugas seperti mengerjakan Lembar Kerja Siswa kemudian dibahas bersama-sama dan diberi nilai agar siswa tetap semangat dalam belajar.

Berdasarkan hasil wawancara dengan Ibu Siti Fatimah, S. Pdi dapat diketahui bahwa jika ia tidak dapat mengajar, ia memberikan tugas seperti mengerjakan Lembar Kerja Siswa dan memberikan nilai pada tugas tersebut. Hal ini dimaksudkan agar siswa tetap belajar meskipun tidak diawasi oleh guru.

\section{Kendala yang dihadapi dalam peningkatan profesionlitas guru dalam pembelajaran Pendidikan Agama Islam di MTs Arrohmaniyah NW Senyiur}

Sebagaimana pembahasan sebelumnya, bahwa profesi sebagai guru merupakan tanggung jawab yang sangat besar, sehingga dalam pelaksanaannya banyak kendala yang dihadapi dalam rangka meningkatkan keprofesionalannya. 
Faktor dominan yang menjadi kendala dalam peningkatan keproesionalan guru di MTs Arrohmaniyah NW Senyiur adalah kurangnya minat guru untuk meningkatkan keprofesionalannya melalui jenjang pendidikan yang lebih tinggi. Penurunan gairah dan kemauan guru mengajar akan berdampak terhadap hasil pendidikan.

Berdasarkan hasil wawancara dengan Ibu Dra. Mufidah dapat diketahui bahwa kurangnya minat guru untuk meningkatkan keprofesionalannya melalui jenjang pendidikan yang lebih tinggi disebabkan oleh kesejahteraan yang diperoleh guru kurang memadai sedangkan jam mengajar sangat padat. Oleh karena itu, upaya untuk menambah pengetahuan menjadi terhambat karena dana tidak ada. Rendahnya kesejahteraan yang diberikan kepada guru tersebut mengakibatkan ia harus mencari alternatif lain sebagai sumber penghasilan.

Sangat sulit rasanya seorang guru yang hanya mengandalkan gajinya untuk memenuhi semua kebutuhannya, walaupun dalam standar minimal. Ini adalah sebuah kehidupan yang ironis, dimana seorang guru dituntut untuk memenuhi persyaratan administrative, akademis, dan kepribadian harus menghadapi kehidupan yang sangat timpang antara pendapatan dan pengeluaran.

Penghasilan yang diperoleh guru hanya mampu memenuhi kebutuhan harian keluarga. Oleh karena itu, upaya untuk melanjutkan ke jenjang pendidikan yang lebih tinggi menjadi terhambat. Hal ini sesuai dengan hasil wawancara dengan Bapak Drs. Suryadi selaku Wakil Kepala Sekolah di MTs Arrohmaniyah NW Senyiur yaitu kalau seandainya kuliah S2 itu yang membiayai sekolah atau pemerintah, maka semua guru di sini mau untuk melanjutkan. Tetapi, karena untuk melanjutkan kuliah itu dengan biaya sendiri maka lebih baik anaknya saja yang sekolah.

Pemenuhan kebutuhan hidup merupakan suatu yang harus diupayakan oleh setiap individu. Bagi seorang guru kebutuhan hidupnya bukan hanya sandang, pangan dan papan, melainkan juga kebutuhan untuk menambah wawasan dan pengetahuan agar ia mampu mentransformasikan ilmu pengetahuan kepada siswa sesuai dengan perkembangan ilmu pengetahuan dan teknologi serta adat istiadat yang terus berkembang di tengah mayarakat.

Upaya peningkatan profesionalitas guru dalam pembelajaran Pendidikan Agama Islam di MTs Arrohmaniyah NW Senyiur 
Peningkatan Keprofesionalan Guru Dalam Pembelajaran Pendidikan Agama Islam di MTs Arrohmaniyah NW Senyiur

Upaya peningkatan profesionalitas guru dapat diketahui dari hasil wawaancara dengan Bapak Drs. Suryadi, bahwa faktor penunjang peningkatan keprofesionalan guru antara lain: latar belakang pendidikan guru, pengalaman guru mengajar, kedisiplinan dan pengawasan, serta tersedianya sarana dan prasarana.

Berdasarkan hasil wawancara, dapat diketahui bahwa guru-guru Agama di MTs Arrohmaniyah NW Senyiur, kebanyakan guru mempunyai latar belakang pendidikan, pengalaman mengajar, dan penataran untuk meningkatkan keprofesionalannya. Selain itu juga tersedinya sarana dan prasarana juga mendorong usaha guru.

Seorang guru yang merasa berkepentingan meningkatkan kualitasnya, maka ia akan tergerak untuk melakukan usaha-usaha yang dapat menunjang peningkatan wawasan pengetahuan, sikap dan keterampilan, baik melalui kegiatan-kegiatan yang diselenggarakan oleh sekolah seperti rapat, seminar, penataran, dan sebagainya.

Bertolak dari tugas dan tanggung jawab guru Pendidikan Agama Islam adalah pengajar dan pendidik materi Pendidikan Agama Islam, maka untuk menjadi guru yang profesional dalam menjalankan tugasnya harus menguasai beberapa kompetensi. Berdasarkan hasil wawancara dengan Ibu Dra. Mufidah, maka kompetensi yang harus dimiliki oleh guru Pendidikan Agama Islam di MTs Arrohmaniyah NW Senyiur adalah sebagai berikut:

1) penguasaan terhadap materi atau bahan pelajaran

2) mengelola program belajar mengajar, ini disesuaikan dengan materi

3) mengelola kelas, maksudnya bisa menguasai kelas agar kegiatan yang dilaksanakan dapat berjalan dengan lancar dan baik

4) menggunakan media, misalnya pendidikan untuk meningkatkan keimanan dan ketaqwaan pada Allah SWT dengan berdasarkan pada Al-Qur'an dan Hadits

5) mengelola interaksi belajar mengajar

6) menilai prestasi belajar mengajar.

Upaya untuk meningkatkan kualitas guru Pendidikan Agama Islam di MTs Arrohmaniyah NW Senyiur tidak hanya dengan menguasai kompetensi-kompetensi tersebut, tetapi bisa juga dengan mengikuti seminar, penataran, Musyawarah Guru Mata Pelajaran. Berdasarkan hasil wawancara dengan Ibu Siti Fatimah, S. Pdi, bahwa untuk meningkatkan keprofesionalannya sebagai guru Pendidikan Agama Islam ia 
mengikuti seminar, penataran, dan workshop. Hasil wawancara ini merupakan kenyataan yang baik. Karena dengan adanya usaha dari pribadi guru Pendidikan Agama Islam untuk mengembangkan kemampuan dan kompetensinya sekaligus meningkatkan kualitas yang harus mereka miliki menunjukkan bahwa dedikasi dalam mengembangkan tanggung jawab mendidik masih tinggi.

Usaha-usaha selain yang dilakukan oleh guru tersebut juga ada usaha-usaha yang dilakukan oleh Kepala Sekolah yang harus diikuti dan dilaksanakan oleh guru Pendidikan Agama Islam untuk meningkatkan pengetahuan, sikap dan keterampilannya. Hal ini untuk menunjang pelaksanaan tugas guru Pendidikan Agama Islam di sekolah.

Berdasarkan hasil wawancara dengan Bapak Drs. Suryadi selaku Wakil Kepala Sekolah, usaha-usaha yang dilakukan oleh sekolah untuk meningkatkan keprofsionalannya adalah penyediaan sarana dan prasarana, kedisiplinan dan pengawasan, rapat dan penataran.

Kedisiplinan sangat penting untuk membina pertumbuhan jabatan guru, dengan adanya kedisiplinan dan pengawasan yang baik dari Kepala Sekolah, maka guru akan lebih hati-hati dan bertanggung jawab terhadap tugas yang dibebankan kepadanya. Melalui pengawasan ini Kepala Sekolah harus memaksimalkan membantu memecahkan kesulitan yang dihadapi guru.

Menurut Bapak Drs. Suryadi, kesalahan yang dihadapi guru hendaknya dilakukan secara bijaksana. Kedisiplinan dan pengawasan ini diharapkan dapat menciptakan moral kerja yang baik di kalangan guru dan seluruh staf karyawan.

Sedangkan rapat dilakukan untuk mengevaluasi pelaksanaan tugas guru serta membahas masalah-masalah yang ada kaitannya dengan pembelajaran disekolah. Adapun tujuan-tujuan dari rapat tersebut adalah:

1) meningkatkan kerjasama atau kesetiakawanan

2) memberi informasi kepada guru tentang perkembangan sekolah

3) meningkatkan pengertian guru terhadap seluruh aspek kegiatan sekolah yang bersifat menyeluruh dan terpadu

4) memberikan informasi tentang perkembangan baru dalam dunia pendidikan yang dapat diberikan kepada guru

5) memberikan wahana bagi bagi pertukaran gagasan antara guru

6) menyadarkan guru akan masalah yang dihadapi sekolah 
7) membina guru dalam profesinya

8) menjadi umpan balik terhadap kemajuan atau kemunduran dari lembaga.

Oleh karena itu, untuk memperluas pengetahuan hendaknya para guru Pendidikan Agama Islam lebih meningkatkan lagi usaha-usahanya dan sebagai Kepala Sekolah juga mengadakan jenis-jenis usaha dalam bentuk lain yang dapat menunjang peningkatan pengetahuan dan keterampilan yang baru agar para guru lebih berpengalaman. Dengan demikian, hasil analisis yang ada tersebut dapat diketahui wujud nyata adanya usaha-usaha peningkatan keprofesionalan guru Pendidikan Agama Islam baik yang dilakukan oeh guru Pendidikan Agama Islam maupun usahausaha dari sekolah itu.

Faktor lain yang dilakukan sekolah untuk meningkatkan keprofesionalan guru adalah dengan mengadakan seminar. Berdasarkan hasil wawancara dengan Ibu Dra. Mufidah dapat diketahui bahwa di MTs Arrohmaniyah NW Senyiur dulu para guru sering mengikuti seminar, akan tetapi sekarang yang mengikuti seminar hanya perwakilan satu sampai dua orang sekota Malang. Apabila ada ilmu baru, kemudian ditransformasikan melalui Musyawarah Guru Mata Pelajaran.

\section{Kesimpulan}

Berdasarkan hasil penelitian yang dilakukan tentang "Peningkatan Keprofesionalan Guru dalam Pembelajaran Pendidikan Agama Islam" di MTs Arrohmaniyah NW Senyiur dapat disimpulkan sebagai berikut:

1. Profesionalitas yang dimiliki oleh guru dibuktikan dengan semua guru memikili ijazah keguruan yang menjadi syarat profesional, memiliki pengalaman mengajar lebih dari lima tahun berarti mempunyai kesempatan untuk mengembangkan kualitasnya, setiap kali akan mengajar selalu membuat rencana pembelajaran, metode yang digunakan bervariasi disesuaikan dengan materi yang diajarkan dan disesuaikan dengan kondisi, melakukan situasi interaksi yang baik dengan siswa, dan selalu mengadakan evaluasi pada setiap selesai satu pokok bahasan.

2. Kendala yang dihadapi oleh guru dalam peningkatan profesionalitasnya adalah padatnya jam mengajar dan tidak adanya minat untuk melanjutkan pendidikan ke jenjang yang lebih tinggi karena kesejahteraan yang diberikan kepada guru kurang memedai.

3. Adapun upaya-upaya yang dilakukan dalam peningkatan profesionalitas guru Pendidikan Agama Islam di MTs Arrohmaniyah NW Senyiur telah nyata, baik 
yang dilakukan oleh guru maupun kebijakan dari Kepala Sekolah. Upaya yang dilakukan oleh guru adalah menguasai kompetensi dalam menjalankan tugasnya, sedangkan upaya yang dilakukan oleh Kepala Sekolah yang dilaksanakan oleh guru Pendidikan Agama Islam adalah penyediaan sarana dan prasarana, kedisiplinan dan pengawasan, rapat guru, seminar dan penataran.

\section{Daftar Pustaka}

Al Abrasy, M. Athiyah, 1979, Dasar-Dasar Pokok Pendidikan Islam (Jakarta: Bulan Bintang)

Arikunto, Suharsimi, 1998, Prosedur Penelitian Suatu Pendekatan Praktek, (Jakarta: Rineka Cipta)

UURI, Sisdiknas, (Bandung: Citra Umbara, 2003)

Poerwadarminto, S. Wojowasito, WJS, 1982Kamus Bahasa Inggris IndonesiaIndonesia Inggris (Bandung: Hasta)

Salim, Yeny Salim, 1991, Kamus Indonesia Kontemporer, Moderninglish (Jakarta: Pres)

Sadirman A. M, 1991, Interaksi dan Motifasi Belajar (Jakarta: Rajawali Pres)

Arifin, M. 1993Kapita Selekta Pendidikan Islam dan Umum (Jakarta:)

Marimba, Ahmad D., 1980, Pengantar Filsafat Pendidikan Islam (Bandung: Al Maarif)

Indrakusuma, Amien Daiem, 1993, Pengantar Ilmu Pendidikan (Surabaya:Usaha Nasional)

Undang-Undang Republik Indonesia, 2003, Sistem Pendidikan Nasional (Bandung: Citra Umbara)

Darajat, Zakiah, 1992, Ilmu Pendidikan Islam ( Jakarta: Bumi Aksara)

Saifullah, Ali, 1989, Antara Filsafat dan Pendidikan (Surabaya: Usaha Nasional)

Usman, Moh. Uzer, 1994, Menjadi Guru Profesiona, (Bandung: Remaja Rosda Karya..)

Tim Pembina Matakuliah Didakdik Metodik, 1981, Kurikulum PBM (Surabaya: IKIP Surabaya)

Sahertian, Piet A, 1990, Super Visi Pendidikan Dalam Rangka Program Inservice Eduacatio (Surabaya:.Usaha Nasional)

Sudjana, Nana, 1991 Dasar-dasar Proses Belajar Mengajar (Bandung: Sinar Baru)

Nasution, 1962, Teknologi Pendidikan (Bandung: Jenmers)

Surakhmad, 1980, Pengantar Interaksi Mengajar Belajar, (Bandung: Tarsito)

Arif 1982, Pengantar penelitian dalam Pendidikan, (Surabaya: Usaha Nasional)

Hadi Sutrisno, 1990, Metodologi Penelitian Research II, (Yogyakarta: Andi Offset) 